\title{
Development Model Of Typical Regional Product Marketing Based on Employee Development For Entering The Centralized Market
}

\author{
Zaleha Trihandayani ${ }^{1}$, Ahmad Ady Arifai ${ }^{1}$ and Sabil ${ }^{1}$ \\ \{ehakeko@gmail.com\} \\ ${ }^{1}$ Universitas Muhammadiyah Palembang, Indonesia
}

\begin{abstract}
Opportunities for business people to contribute and promote the economy very important to enhancement the market activity that are in the area, regional economy will be weak if not supported by the strength of the opportunity businesses. The power unit of anyl businesses in the region is in anticipation to avoid Hollow Middle is a medium-sized and large enterprises that strength and weakness to go nationally and internationally. Competitive advantage typical regional products are not only influenced by the employee advantages, but is also influenced by the human resources (HR) and Operational in shaping the development of local specialty products, employee to enter the centralized market. It can be concluded that; First, internal factors against and employee development for centralized market negative effect. Secondly, the positive effect centralized market on the entering development._Third, external factors on entering development and centralized market influence positively. Fourth, the internal factors of the employee development and market centre was not significant._Fifth, while also not significant employee development to centralized market. Sixth, external factors on development of labor and significant centralized market.
\end{abstract}

Keywords: Typical model regional product marketing, employee development , centralized market

\section{INTRODUCTION}

The increasing establishment of shopping centers in particular modern markets is not expected to leave the advantages of industrial products and employee in Indonesia, there for not this kind of existensi employee in the global enterprises . Improved product quality is necessary to increase the volume of sales of each product is typical of the area [1]. Opportunities for business people to contribute and promote the economy can be seen by the size of the market activity that are in the area, the regional economic structure becomes weak if not supported by the strength of the structure businesses.

The prepare of speed growing trade foods caused by the position Palembang metropolitan city improve of Palembang destination located development of growth industrialized countries such as developed country, Singapore, Malaysia and Thailand. South Sumatran capital 
Palembang as to be ready to capture these opportunities and can provide shopping centers representative. Palembang is nice city have many products, namely: pempek, kemplang, songket cloth and carving in the closet, this products hope to make many products improve as a superior product from outside the region and even foreign countries.

Palembang one from many City progress to destination should make ready to become international trade for economic factors, there are many business capabilities example foods should be enhancement, especially for business people who come from region of Palembang such as pempek where the majority of whom many are engaged in small industry and this opportunities to make the city will very nice, besides improving the quality of products and market expansion is very important to note.

Capability of business in Palembang city, many programs will do in this city, superior of products using traditional way, it is very different from which a many people can become entrepreneurs to enhancement other business so qualified, Japan, Korea generally someone to be an econom is prepared in advance by schools in business or entrepreneurship [2]. When the important industry to make qualified, many people do their skill prepared in such a way it can avoid many education and behavior both in terms of time, money, creativity development and market themselves.

A superior product of Palembang has a national and international market, to get cloth of songket example, we may encounter region this product domestic bungle or other nice region, there are pempek in a along the main streets in the Palembang, crackers can be need innovation product at the long streets and in the opposite ulu Ulu City Palembang, while the many carved can enhancement in the area of the Mosque of Palembang. Therefore, the location of this superior product is very difficult if we want to buy alls so market for the products of Palembang must in a narrow place, especially for innovation songket and carving the cabinets very important to make innovation so this product exclusive to sell in global market.

Centralized market need to be established for a nice product of city because its very important to growth this innovation so superior of foods coming in the market and consumers easier to find thats, besides that if a important product is a nice placed in the market to facilitate the consumers in or outside the region know and consume The product [3]. This will make the typical product Palembang still will not be abandoned despite the entry of various similar products from outside the area

The development of labor-based marketing model that is marketing model that was developed through development of employee by PT. Sosro rays which can make it easier and profitable for the seller. If the homogeneity of superior products can be developing, this is interesting for many people to coming maintain the quality of the superior product from Palembang there will be competition among traders who improve of superior products that can be reach for domestic and international market to consumersl as foreign countries, so the important to get the quality products can increase the sales volume for the product superior from Palembang.

This riset by analyzing the situation, determine seqmenting, targeting and positioning of products as well as designing a marketing strategy, strategic relations and the enhancement of employee [4], to make it easier to enter the centralized market (market center) which central the superior regional products as well to enhancement the existence of econom are growth industries and handicrafts. Product of regional from Palembang can growth quality product to entering national and international market, quality product from superior product as well as kemplang from Tailand, Kemplang do not have many water from Palembang. 
This study purpose is; (1) analyze the situation of regional products to enhancement to coming national and international market (2) do the regional product segmenting position of regional products, (3) forming of the strategy, development of marketing programs, enhancement employee and operation , (4) Analyze the factors typical regional products entering the centralized market, (5) models typical regional products based development of employee.

\section{LITERATURE REVIEW}

Marketing model based employee development has been studied and carried out by company to analyze the situation, determine market segmentation, determining the target market positioning of products and skill of employee [4]. Analysis by company to enhancement the regional product so the quality product growth to coming at competition di global market. But in these studies doesnot studies about strategy marketing.

Development Market based employee development about market strength as the base product excellence and the actually how the people can use the quality product to win in the market global [4].

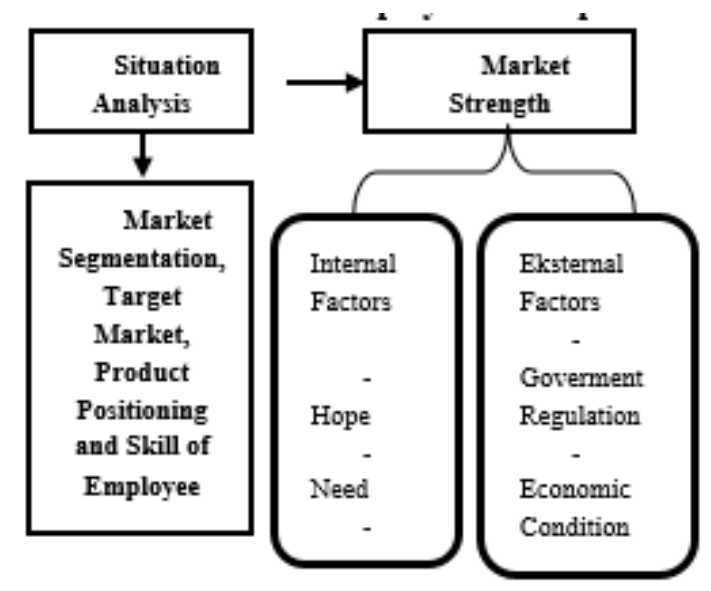

Fig. 1 Typical Regional Product Marketing Model Employee Development towards: PT Sinar Sosro Case

Products marketing model based employee development by adding the design of marketing strategies, relationship strategies and the employee development in research . its tested for validity and effectiveness of the marketing model.

The situation analysis, situation analysis conducted to determine the internal - external environmental conditions affecting the typical products of local businesses, hopes the enhancement the employee can makes the quality of regionalproduct [5].

Information in an enterprise located in the information of management system Mechanism acquisition, more specifically on information of marketing. The devices SIM there is: (a). Good system of internal business of: foods or superior product to the marketing, sales information systems, (b). Marketing Intelligence System, the important information about the 
development of needs for consumers to buy many product. (c). The quality product to get competitors with business di global market so the superior product coming in national and international market [6].

Market segmentation, segmentation make the position same with the needs consumers so the quality enhancement the superior product becomes the best and qualified [7]. Kotler [8] Information of product is very important because people hope the product can make the good quality as well as customers based on characteristics. Once the group is formed, enhancement do is to identify each consumer characteristics to be used as the profile of each segment. Profile is then a differentiating factor from each segment [9].

The Target Market, Through a clear mapping of the consumer, a business will be easier to choose where the consumer segment that will be the target market. The important foods for many consumers will make targeted and needs innovation for developing, entering the market, and use many ather strategies in general,. Product positioning, Positioning is an activity undertaken by business units in designing the offer and image in order to get a place where esier for consumers. Perform positioning, necessary differentiation of the product offering to consumers to enhancement the quality superior product [10]. As a culture, market orientation contains guidelines that direct the behavior of people in comapnys. Narver [11] make the spesiality of product growth.Marketing Strategy, through the analysis of the spesiality of combine quality product to get competition in central market, to segment the market, competitor evaluation, and make the behavior of consumers choose the superior product. Important to make the designing a marketing strategy,. Establishing global marketing, and developing skill and behavior for employee to make other foods. An understanding of market conditions and competition enhancement to make innovation to superior procuct from special city. To be able to quickly anticipate these changes, the typical product business unit must quickly identify changes. Knowing what is happening and enhancement many innovation for the future.

Strategies relationship, A good relationship needs to be established between the local specialty products business unit with the end consumer, distribution channels, retailers), suppliers, competitors have the same work with business units, the qualified people of local specialty products business unit. Good relationships can encourage business units to improve its ability to satisfy the consumer and can quickly identify changes in the environment through cooperation related parties.

Development Marketing, [12] strategy marketing and development employee can make the quality superior productis a cornerstone in the preparation, implementation, and control of the company's marketing strategy, the strategy of marketing mix or marketing mix (4P for the product): : a. Product, related to the differentiation in terms of shape, features, design, and others. b. Price, relating to how to determine the price of products or services. c. Placement, consumers can easier to found this distribution channels for product from the country, its will important.

Many company in Palembang to produce superior product must be enhancement quality product from development employee. This action can make differential product so streght of product will growth to comes in global market within other product from other foreign.

Human Resources Development and Operations, development of human resources and operations taking into account in company to make many innovation and enhancement for skill and behavior employee, strategies for achieving objectives, the nature and type of activity, the type of technology used, and external factors such as government policies, development of employee [13]. 
Government support to promote condition of company in the country is very great contribution and dynamic growth to the development of marketing programs . Innovation product will do for the business in superior product to can competition di central market.

The Government has launched the innovation -based economy by 2025 , with a seven-step improvement innovation ecosystem, turn four vehicle acceleration of the economic growth that the basic needs of the industry, creative industry, differential of product will be important to make this product in global market of the area -based industries and strategic industries. This is the basis for the development of employee as follows:

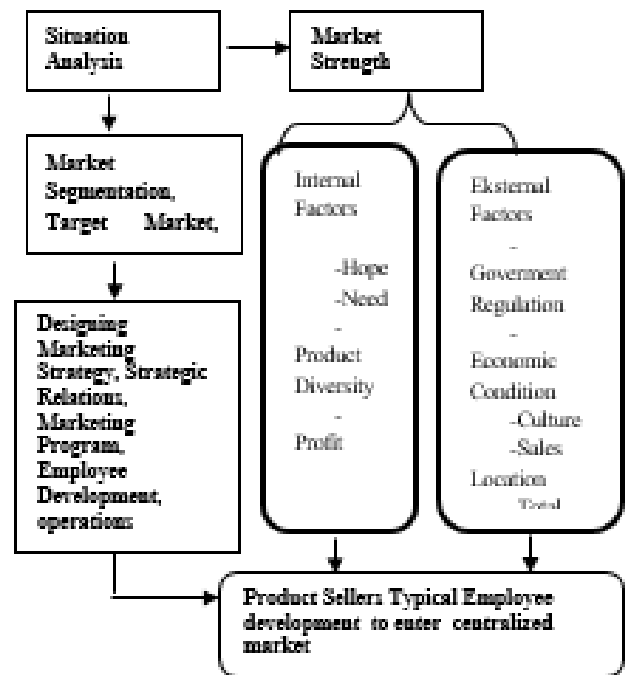

Fig. 2 Product Marketing Model DevelopmentTypical Areas Based on Employee Development

\section{RESEARCH METHODOLOGY}

The operational definition, the development employee in the company,.The employee development-based marketing model by analyzing the situation, determine market segmentation, target market and positioning of products and designing marketing strategies, relationship strategies and employee development

Innovation of superior product from superior its can be enhancement skill to make the company win the competition in market centre and in national or international market. Training and development as well as needs to growth quality product for innovation product in Palembang to cones market centre.

Table 1. Typical Areas shape Product Differentiation

\begin{tabular}{llll}
\hline $\begin{array}{l}\text { Form of } \\
\text { Differentiation }\end{array}$ & $\begin{array}{l}\text { Name of } \\
\text { Differentiation }\end{array}$ & Notes & Example \\
\hline Product & Product Form & Size, Color, Physical Form & Logo, packaging, label \\
& Feature & Additional benefit from main product & Characteristic \\
& Performance & The degree to which the main & Typical products which \\
characteristics of the product operates. & have a broad market \\
& Conformance & specifications and the same & Songket with the onset \\
\hline
\end{tabular}




\begin{tabular}{|c|c|c|c|}
\hline $\begin{array}{l}\text { Form of } \\
\text { Differentiation }\end{array}$ & $\begin{array}{l}\text { Name of } \\
\text { Differentiation }\end{array}$ & Notes & Example \\
\hline & quality & $\begin{array}{l}\text { manufactured products able to make } \\
\text { quality of product can growth }\end{array}$ & thread \\
\hline & Durability & $\begin{array}{l}\text { Operating life expectancy of products } \\
\text { under normal conditions or stress }\end{array}$ & $\begin{array}{l}\text { Carved cabinets are } \\
\text { durable for years of usage }\end{array}$ \\
\hline & Reliability & $\begin{array}{l}\text { The ability of the product to be a failure } \\
\text { or error in a certain period }\end{array}$ & $\begin{array}{l}\text { Typical products can } \\
\text { Entering the national and } \\
\text { international markets }\end{array}$ \\
\hline & Repairability & $\begin{array}{l}\text { Ease of repair products that are } \\
\text { damaged or malfunction }\end{array}$ & $\begin{array}{l}\text { Improvements to the } \\
\text { typical regional products }\end{array}$ \\
\hline & Style & The look and feel of a product & $\begin{array}{l}\text { Innovation of superior } \\
\text { products in market }\end{array}$ \\
\hline & Design & $\begin{array}{l}\text { Features that affect how the function } \\
\text { and appearance of the product }\end{array}$ & $\begin{array}{l}\text { Songket modified with } \\
\text { embroideries and } \\
\text { jumputan }\end{array}$ \\
\hline
\end{tabular}

Population and sample, this study is the people that they sells and consumers of superior product in Palembang city that very nice to bring there from Palembang, South Sumatra number is not known for certain (infinite). This reseach using the technique of purposive sampling to get sample that make this objective or valid to the research objectives, in this research that sellers and buyers of products superior Palembang scattered in the Ladder Tank, , Region Mosque, opposite ulu, market of 16 Ilir, cinde market, Airport Store crackers kemplang and pempek along Sudirman street have many product pempek food and kemplang, Basuki grace street have many superior food from Palembang, Radial Road have good quality product pempek and kemplang food, Colonel Iskandar street and Kapten A Rivai street is the same. The great mosque have many carve from Palembang and the staircase area have many cloth of songket

\section{RESULTS AND DISCUSSIONS}

Analysis for this research of one system that used to established the model as figure 3 and figure 4.

Internal factors adversely affect the based development employee -0.24 . Internal factors also impact negatively on the centralized market, the path coefficient -0.05 . While employee development positive effect on centralized market of 0.22. External effect positive for market centre towards development of labor, the path coefficient of 0.96. External factors also impact positively on the centralized of market, coefficient of 0.48 .

Internal factor is significant to development of labor, the path coefficient -3.26. Internal factor is not significant to centralized market, the path coefficient -0.52 . While based employee development is not significant to centralized of market, this showed that coefficient is 1.42 .

External factor is significant influence employee development, the path coefficient 4.84 . External factor the result coefficient is 2.54. One of the many business at city will biggest and important enhancement to developing skill employee to make innovation product of superior in market. Though creative ideas are supported by the availability of resources could be one of support for the business to dominate the market. 


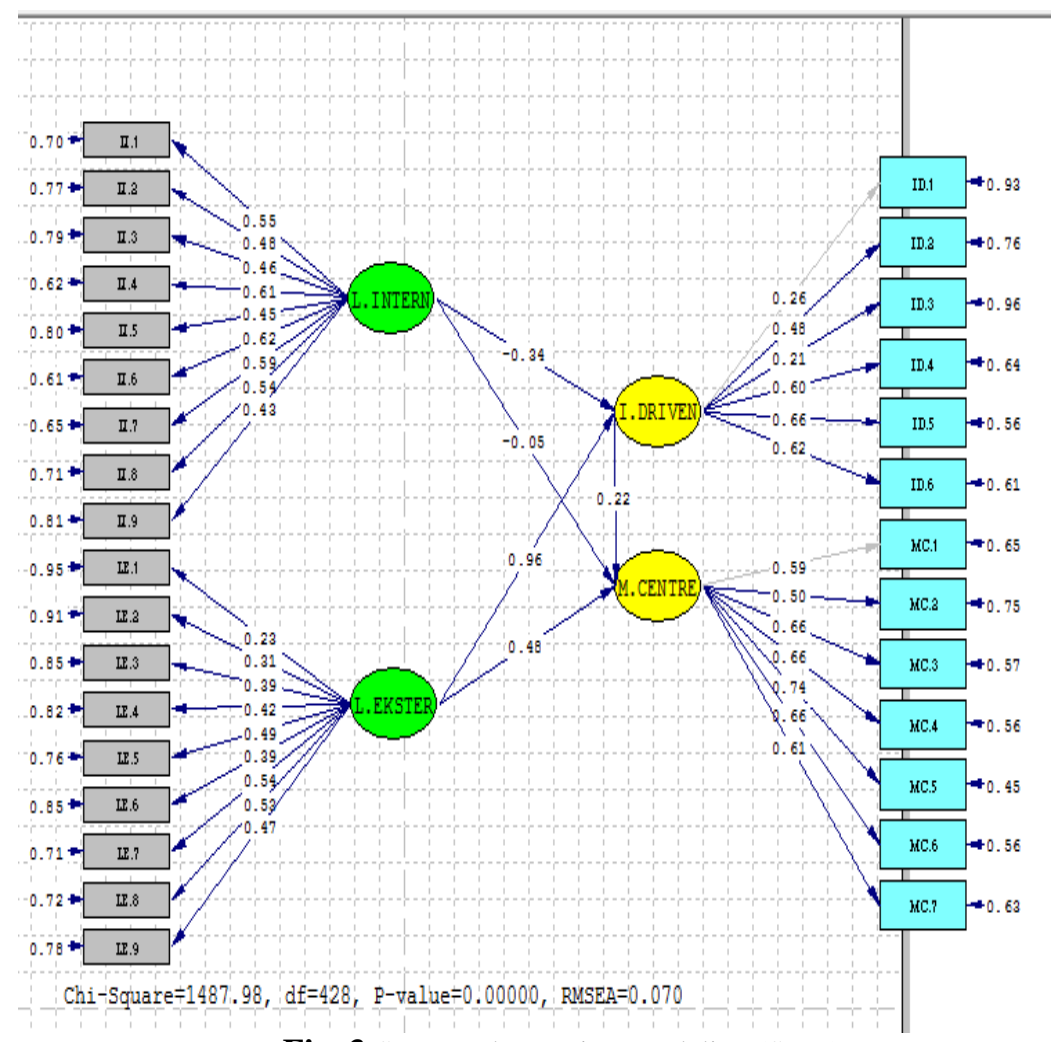

Fig. 3 Structural Equation Modeling (SEM)

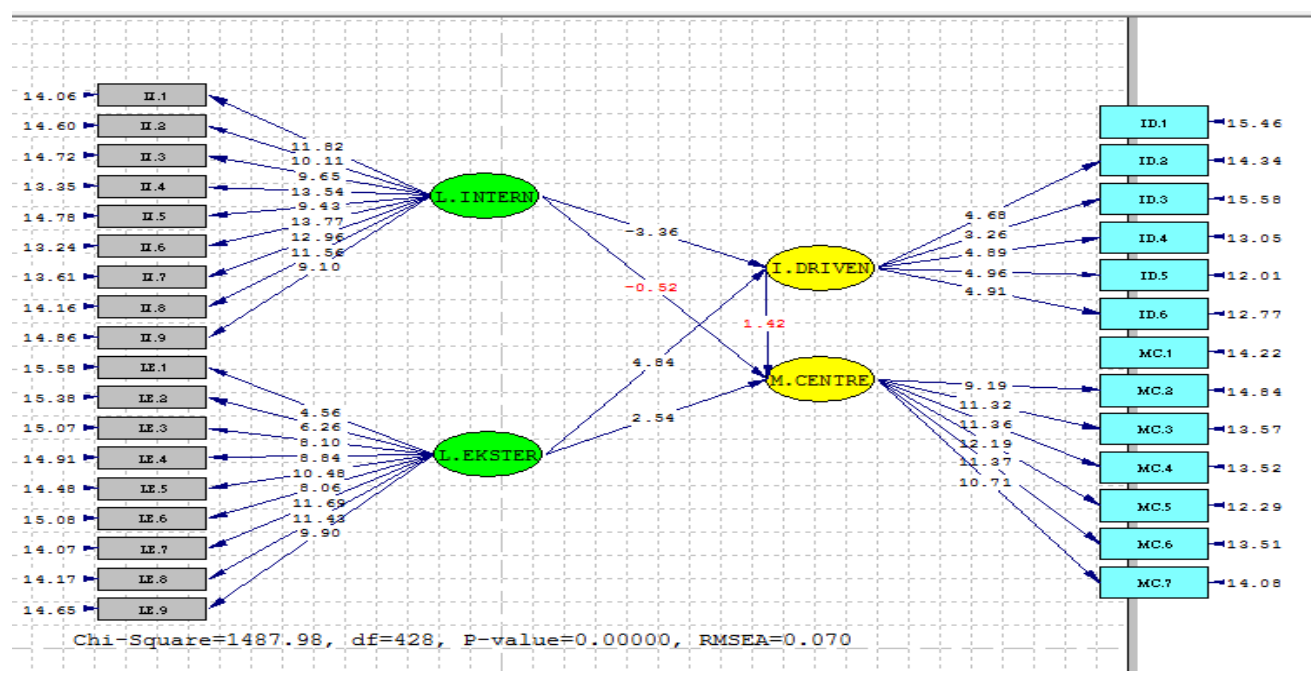

Fig. 4 Structural Equation Modeling (SEM) 
Examples of local products that can compete up to the level of national and even international level. All local products with superior quality that usually starts from small businesses to reach local markets. Before preparing to compete at a higher level, optimize marketing strategies, the local market is important to gain business success.

Employee for development is major component increased competitiveness. such as the quality and trendy. Results of the application of superior foods to come in global market: (a) make the product different to customer preferences, (b) quality improvement resulted in increased prices, (c) important to enhancement quantity of production, (d) an increase in production efficiency and (e) an increase in the value added (Simatupang1991). Thus the application of employee development can produce a product that has a higher competitiveness, such as product quality improvements, improved product design, or increase production efficiency. One real satu pengaruh application of innovation in the production system is to increase production efficiency, which means that a typical product can be produced with less cost, so that the product make the good price to consumers. In addition to suppress the price, the application employee of development is also able to close the gap between the needs of labor and the supply of products by the seller. Through the application of innovation, a product can be made diverse and unique enhancement needs a new trend in the international market preferences. In applying innovation to consider the needs of customers. Adoption of innovations without regard to customer needs will only result in failure of the product when marketed [14].

\section{CONCLUSION}

First, internal factors against and employee development negative effect. Second , employee development positive influence on centralized market. Third, external factors on employee for development and market centre influence positively. Fourth, the internal factors of the employee of development and market centre were not significant. Fifth, while also not significant development of labor to centralized market. Sixth, external factors on employee development and significant centralized market.

Innovation with good system to make important enhancement superior products of Palembang. The role of government is needed, especially in fostering to the bottom line. Second, there should be created a competitive advantage and comparative potential to be used as a trigger to increase competitiveness. Third, good efficiency improvement measures in business and distribution of products. The use of production technologies and inputs / raw materials more efficiently need to be developed. Institutional factors (Bp lift, banking and market) that support production efficiency would need special attention. Moreover in the country need to be , and improvement of infrastructure facilities. Fourth, increase economy and consumers of the priority use of local products, especially the typical regional products. Another thing also need to do, giving the logo on the product, promotion using local and national media, sponsor local events and participate in exhibitions of local and global market. 


\section{REFERENCES}

[1] G. E. Greenley, "Market orientation and company performance: empirical evidence from UK companies," Br. J. Manag., vol. 6, no. 1, pp. 1-13, 1995.

[2] G. Hamel and C. K. Prahalad, "Competing for the future Harvard business school press," Boston, MA, 1994.

[3] R. F. Hurley and G. T. M. Hult., "Innovation, Market Orientation, and Organizational Learning : Empirical Examination," J. Mark., vol. 62, pp. 4254, 2006.

[4] Riamaryani, "Market Driven PT Sinar Sosro," J. Econ., vol. September, pp. 12-13, 2011.

[5] D. W. Cravens, Strategic Marketing, 6th ed. Boston: McGraw-Hill, 2007.

[6] S. Gatenio Gabel, "Social protection and children in developing countries," Child. Youth Serv. Rev., vol. 34, no. 3, pp. 537-545, Mar. 2012.

[7] T. Pawitra, Pemasaran: Dimensi Filsafat. Jakarta: Prasetiya Mulya Business School, 2009.

[8] P. Kotler and K. Keller, Manajemen Pemasaran. Jakarta: Erlangga, 2009.

[9] G. Churchill and D. Lacobucci, Marketing Research: Methodological Foundations, 9th ed. Mason, Ohio: Thomson/South-Western, 2001.

[10] S. W. McDaniel and J. W. Kolari, "Marketing strategy implications of the Miles and Snow strategic typology," J. Mark., vol. 51, no. 4, pp. 19-30, 1987.

[11] J. C. Narver and S. F. Slater, "The Effect of Market Orientation on Business," J. Mark., pp. 20-35, 2008.

[12] J. Dawes, "The Relationship Research between develpment Company Performance Measures in Market Orientation: Further Empirical Evidence," Mark. Bull., vol. 10, pp. 65-75, 2006.

[13] S. Notoatmodjo, "Human Resource Development," Copyr. Rineka, Jakarta, 2009.

[14] M. Merx-Chermin and W. J. Nijhof, "Factors influencing knowledge creation and innovation in an organisation," J. Eur. Ind. Train., vol. 29, no. 2, pp. 135147, 2005. 